\title{
INDUSTRIAL TRANSFORMATION IN RESPONSE TO DETERIORATING TERMS OF TRADE
}

\section{G.Idrisov}

The deterioration of the terms of trade in Russia was the main trigger of sectoral transformation in 2015. Two major specific phenomena have been observed - the redistribution of the generated value added in favor of the extracting sector (despite the plunge of world oil prices) and the absence of any relevant results in the sectors targeted for import substitution (despite the twofold weakening of the ruble). In order to achieve a prompt victory in industrial policy, in our opinion, it will be necessary to implement an exportoriented import substitution model, which will rely on concentration of resources in support of the production and exports of commodities along the value added chains starting in the Eurasian Economic Union (EAEU).

In 2015, the Russian economy underwent significant transformations, and the main of them consisted in the economy's adaptation to the new terms of trade $^{1}$. The deterioration in the terms of trade - that is, a decline of the relative prices for Russia's traditional export commodities (oil, natural gas, metals, timber, chemical products) by comparison with prices of imports - means that for the income derived from the sale of some amount of export products the economy can purchase a smaller amount of imports².

The economy responds to such changes in the terms of trade by a search for a new internal and external equilibrium. A new external equilibrium that is, the return to nearly previous balance of trade - can be achieved sufficiently promptly by adjusting the ruble exchange rate. Imports nominated in rubles become more expensive and therefore less attractive. Exports, on the contrary, gain in competitiveness as a result of the declining costs nominated in dollars. When coupled with the expectations of a relative change in oil prices, the prospects for global economic development and the existing geopolitical risks, this gives rise, almost daily, to new quantitative targets for the ruble's exchange rate against major world currencies ${ }^{3}$.

A new internal equilibrium - that is, the structural adaptation of the economic sectors - occurs, on the contrary, at a rather slow pace. Such a

1 For further details on the factors and dynamics of the Russian economy in 2015, see various issues of The Online Monitoring of Russia's Economic Outlook (OMREO) published by the Russian Presidential Academy for National Economy and Public Administration (RANEPA), the Gaidar Institute and the Russian Foreign Trade Academy (RFTA), available at www.iep.ru

2 For further details on the export and import prices in 2015, see Knobel A. Export-import: era of stagnation. Russian Economic Developments. 2016, No 1 (56), pp. 42-45.

3 For further details on the mechanisms to be applied for achieving a new external equilibrium, see Idrisov G.И., Ponomarev Y. Y. Sinelnikov-Murylev S. G., Terms of Trade and Russian Economic Development. Economic Policy (In Russian). 2015. No 3. pp. 7-37, Goryunov E., Drobyshevsky S., Trunin P. Monetary Policy of Bank of Russia: Strategy and Tactics. Voprosy Ekonomiki (In Russian). 2015. No 4. pp. 53-85; Bozhechkova A. V., Tolstova E. V., Trunin P. V. The analysis of the Bank of Russia's monetary policy./ Russian Journal of Entrepreneurship. 2015. V. 16. No 18. pp. 3041-3052. Bozhechkova A. V., Trunin P. V. Is the Ruble Overvalued? Fundamental Factors of the Real Effective Exchange Rate Movement.. Russian Economic Developments. 2015. No 6, pp. 10-13; Bozhechkova A. V., Knobel A. Yu., Trunin P. V. Balance of Payments Pushed Ruble Upwards. OMREO, No 7 (April). 2015. pp. 6-9. 


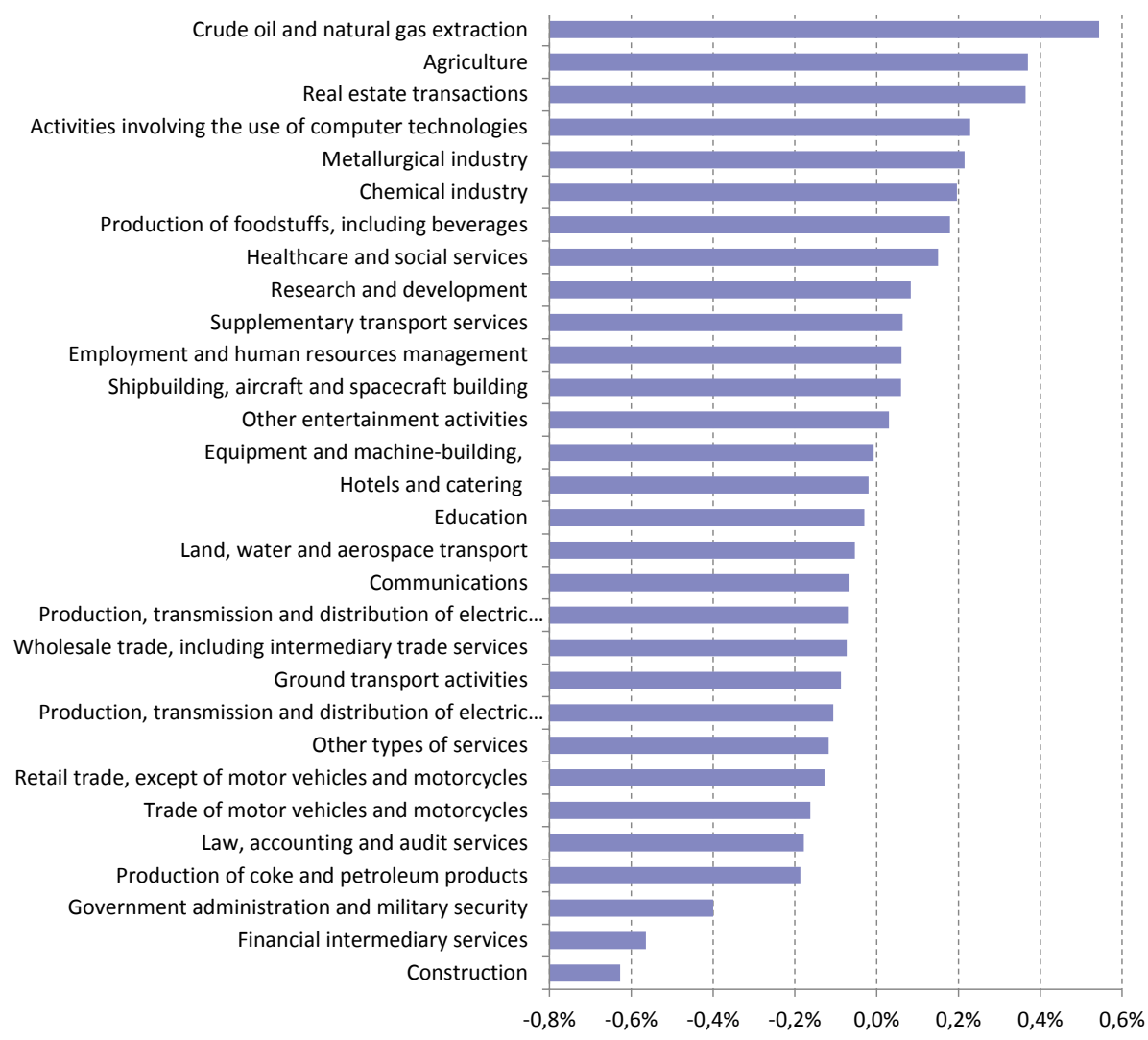

Note. The Types of Economic Activity with Gross Value Added Above Rb 500bn in 2015 (0.7\% of GVA).

Sources: Rosstat; author's calculations.

Fig. 1. Changed Shares in the Value Added Structure, by Type of Economic Activity, 2014 to 2015

transformation results both from the change in disposable income (and the expectations of future incomes) and the multi-paced pass-through effects of the foreign exchange rate on prices, which in their turn result in the labor market's adjustment, structural changes in demand and altered consumer behavior models, the adaptation of the fiscal and monetary policies, and many other changes. In the end, alongside a general output decline, the production structure alters significantly ${ }^{1}$. In this respect, not only the statistical analysis of the structural changes that occurred in 2015 (see Fig. 1) is of interest, but also the interpretation of its content.

At first glance, the picture presented here contains two major paradoxes. First, the development leaders across the economy are the crude oil and natural gas extraction industries. It is not quite clear how such a thing can actually happen, as it is the world prices of oil in particular that plunged, followed by the prices of natural gas, and so these industries could be expected

1 For detailed sectoral development data for 2015, see G. Idrisov, A. Kaukin, O. Morgunova, M. Turuntseva. Russian industry rebounds from the bottom. OMREO, No 15 (November) 2015; G. Idrisov, A. Kaukin, O. Morgunova, M. Turuntseva. The two poles of Russian industry . OMREO, No 12 (September) 2015; G. Idrisov, A. Kaukin, O.Morgunova, M. Turuntseva. The deepening industrial slump: trends have become a fact./ OMREO, No 9 (June) 2015; G. Idrisov, A. Kaukin, O. Morgunova, M. Turuntseva. Industry: trends look worse than actual data. OMREO, No 7 (April) 2015; G. Idrisov, A. Kaukin, O. Morgunova, M. Turuntseva. Decline in industry: worse than desired, better than it seems. OMREO, No 5 (March) 2015. 
to suffer most. Second, no relevant import substitution results are visible. While total GVA declines, the shares taken up by the machine-building and equipment production industry, the production of electronic components, the production of medical equipment, and the production of means of transport have shrunk approximately in the same proportion, so their relative share remains nearly the same. To put it roughly, it will take more than the twofold decline of the national currency's exchange rate and the government's targeted actions to launch a successful import substitution program. Below we will attempt to explain why it happens this way.

Regarding the growth of the extracting sectors of the Russian economy. In early 2015, we described a rather typical picture of how all industries can be arbitrarily divided into 'winners' and 'losers' as a result of a change in the terms of trade on the basis of only two indices - the dependence of each industry on imports of intermediate goods and the exports to imports ratio ${ }^{1}$. Thus, in particular, due to its low dependence on foreign components and high orientation to exports, the extraction of crude oil and natural gas was placed by us in the group of the so-called 'winner' industries. Of course, it is difficult to describe the situation in these industries as positive in face of plummeting world prices of oil. However, due to the delayed ${ }^{2}$ decline of the prices for Russian export oil denominated in USD coupled with the mighty plunge of the ruble's exchange rate and the redistribution of losses generated by the declining prices mainly towards the state budget ${ }^{3}$ and the oil-andgas transfers to Russia's EAEU partners ${ }^{4}$ and away from the corporate budgets ${ }^{5}$, the Russian oil extraction industry has found the new conditions to be favorable to increase production. To put it more simply: the price of Russian export oil denominated in USD is lower, but this price decline is reflected more strongly by the amount of government revenue (export duty) and the oil-and-gas transfer to our integration partners, and not by the incomes of Russian oil and gas companies. So, as a result of the ruble's weakening, one barrel of exported oil generates more rubles for the vertically integrated oil companies, thus creating sufficient incentives for boosting their production volume, given that much of their costs are fixed or quasi-fixed in rubles.

It is interesting to note at the year's beginning, that the perspectives of the other industries were also predicted with sufficient accuracy. Thus, the industries that do not produce export products but use mostly domestic products as their raw materials - the construction materials industry, the cable industry, shipbuilding, the construction sector, financial intermediary services, wholesale and retail trade, and some other industries are not improving their position in the industry structure. This largely has to do with the shrinkage of domestic demand for their goods and services, so that even their higher competitiveness in the domestic market that has improved due to the rising prices of import substitutes does not translate into output growth. And those

1 See Idrisov G. I. The winners and the losers: the effects of new terms of trade on Russia's industry. Russian Economic Developments, No 4, 2015, pp. 26-29.

2 Relative to the decline of world quotes.

3 On the fiscal policy specificities geared to the oil producing countries, see Knobel A. The Risks of Fiscal Policy in Countries Rich in Natural Resources. Economic Policy (In Russian). No 5, 2013. pp. 29-38.

4 See Knobel A. Yu. Eurasian Economic Union: Prospects and Challenges for Development. Voprosy Ekonomiki (In Russian). 2015. No 3. pp. 87-108.

5 For more details, see Bobylev Yu, Idrisov G., Kaukin A., Rasenko O. Oil, budget and tax maneuver. OMEO, No 15 (November 2015), pp. 11-14. 
industries whose share in exports is high and the dependence on imports is low - metallurgy, the chemical and petrochemical industries, the production of leather, agriculture - have considerably increased their competitiveness in the foreign markets as a result of the weakening national currency. Of course, in this connection it is important to note that if the government's attempts to impose constraints on the tradability of goods - that is, the introduction of pricing and technical methods of control over exports in order to prevent shortages of certain products in the domestic market (the introduction of export duties on cereal grains and metals, physical closure of export terminals, restrictions on the assignment of railway carriages to exporting routes) - were to be successful, the relative positions of those industries could have been exactly opposite.

Regarding the difficulties in the launch of import substitution mechanisms ${ }^{1}$. The most typical representatives of the 'losers' are the automobile industry, machine-building, the pharmaceutical industry, and the production of electrical equipment. It is these industries that are the focus of attention in the course of a search for relevant import substitution results. The main obstacle in these industries for a successful launch of import substitution is the considerable cost of the imported intermediate products or the domestic exports, and so they predominantly manufacture complex technical products for the domestic market. As a result, the three major mechanisms contributing to import substitution - the national currency's weakening ${ }^{2}$, constraints on the tradability of goods and targeted government actions ${ }^{3}-$ cannot offset the negative effects of the general uncertainty, the difficult access to borrowed funds, and the rising costs associate with the more expensive foreign intermediate products and domestic exports. The upshot is that neither the aggregate statistics on the share of foreign products in the domestic market ${ }^{4}$ nor the statistical data on the shares of different industries in total GVA show any signs of import substitution.

In our opinion, it is worthwhile to speak of the actual results of the current phase of import substitution in Russia only with regard to the technically simple or hi-tech products, on condition that the first link in each value added chain can be found in the EAEU's territory, given that this must be primarily the substitution of imported products not inside Russia, but in the foreign markets. This is the so-called export-oriented import substitution model. To launch this model, it will be necessary:

- to completely abandon those government support tools that cannot be estimated in terms of transparent performance indices, do not allow the establishment of any distinct timelines for the achievement of product competitiveness on a global scale, and envisage no loan budget repayment, in particular direct budget subsidies, contributions to charter capital, and the imposition of import tariff and non-tariff constraints;

1 In addition, see Idrisov G., Ponomareva E., Import Substitution Policy and the Competitiveness of the Russian Economy. Russian Economic Developments, No 10, 2015, pp. 64-66

2 For the impact of the behavior of import prices and the foreign exchange rate on the volume of imports, see Knobel A. Estimation of import demand function in Russia./ Applied Econometrics. 2011, No 4 (24).pp. 3-26.

3 For further details, see Kaukin A., Pavlov P., Import Substitution in the Processing Industry: Weak Effect./ OMEO, No 3 (21) (February 2016).

4 Ibid. 
- to discontinue the support of those enterprises whose short-run and long-run value added cannot achieve competitive advantages over their foreign analogues ${ }^{1}$ (some products of light industry, the food, electronic, automobile and other industries);

- to ban the imposition of any constraints on the tradability of goods for the competitive sector of the economy or their separate segments whose products successfully compete with their foreign analogues, and so are in demand both in the foreign and the domestic markets (ferrous and non-ferrous metallurgy, production of technical textiles and nonwoven materials, some segments of the chemical industry, the food industry, etc.);

- to concentrate the intellectual, financial and organizational efforts aimed at supporting the production of some hi-tech components of finished products (materials, oil-refining and petrochemical products, industrial components and units, electrical and electronic units and components, software, etc. and their integration into complex technologies and products in transport, energy, and aerospace machinebuilding).

We understand that this is a wide and complex agenda, which envisages the revision of both the Law 'On the Industrial Policy' and the specific import substitution plans for each sector or industry. Regretfully, Russia at present has neither the resources nor the time for implementing a comprehensive targeted import substitution policy. We need targeted efforts in selected sectors and enterprises and prompt victories. In our opinion, if such 'victories' are not achieved in 2016, the current import substitution policy in Russia will be totally failed ('innovation' will become the only term deemed to be worse than that in the public mind), just as it happened in Latin American countries, and Russia will forever lose many of the industries and types of products that are still capable of achieving a world competitive level.

1 No doubt, a specialized sectoral commission should be established for this purpose by the RF Ministry of Industry and Trade, the RF Ministry of Energy, the RF Ministry of Agriculture and other branch ministries, in cooperation with the RF Ministry of Economic Development and the RF Ministry of Finance. 